\title{
SEKTOR WĘGLOWY \\ W SYSTEMIE ENERGETYCZNYM CHIN \\ - PERSPEKTYWY ROZWOJOWE
}

\author{
THE COAL SECTOR IN CHINA'S ENERGY SYSTEM: \\ DEVELOPMENTAL PERSPECTIVES
}

\begin{abstract}
A b stract. The article introduces the mechanism of using coal and its role in China's energy policy. It presents the activities which are significant for the economic and social development. The China's demand for energy doesn't have only economic dimension, but also has an impact on the developmental strategy. It influences on China's aspirations to achieve a stronger position in the global space, as well as its chance to become a responsible world leader in terms of environmental protection.
\end{abstract}

\section{ROSNĄCY POPYT NA ENERGIĘ W CHINACH}

Pod koniec lat 70. Chiny zainicjowały reformy zmieniające dotychczasową strukturę ekonomiczną państwa. Stopniowe odchodzenie od mechanizmów charakterystycznych dla gospodarki planowej i uwzględnianie w szerszym stopniu rozwiązań rynkowych zaowocowało gwałtownym przyśpieszeniem wzrostu gospodarczego. Chiny w ciągu ostatnich ponad trzech dekad rozwijały się w średniorocznym tempie $10 \%$, czemu towarzyszyło znaczące podniesienie dochodów mieszkańców kraju. W 2012 r. PKB Chin wyniósł $51,93 \mathrm{mln}$ RMB (8,28 mld USD), notując wzrost o 7,8\% w stosunku do roku poprzedniego ${ }^{1}$. PKB Chin stanowił w 2012 r. 13,27\% światowego $\mathrm{PKB}^{2}$. Wedle informacji chińskiego Państwowego Biura Statystycznego tylko w okresie

ŁUKASZ GACEK - adiunkt w Instytucie Bliskiego i Dalekiego Wschodu Uniwersytetu Jagiellońskiego; adres do korespondencji - e-mail: lukasz.gacek@uj.edu.pl

${ }^{1}$ China 2012 Growth Eases to 7.8 pct, Xinhua, 18 I 2013.

${ }^{2}$ China GDP, Trading Economics, http://www.tradingeconomics.com/china/gdp (23 XI 2013). 
2005-2010 udział PKB Chin w światowym PKB wzrósł z 5\% do 9,5\%. W 2010 r. stanowił on 40\% PKB Stanów Zjednoczonych, podczas gdy pięć lat wcześniej tylko $18 \%{ }^{3}$. Pomimo tych znaczących sukcesów Chiny, uwzględniając ogromną, ponad 1,3-miliardową populację, nadal pozostają krajem rozwijającym się. Chociaż i tu należy zauważyć dynamiczny wzrost dochodów przypadających na głowę mieszkańca. To, co zwraca szczególną uwagę, to fakt, że w latach 1990-2012 PKB per capita zwiększył się dwudziestokrotnie, a na przestrzeni tylko ostatniej dekady ponad sześciokrotnie ${ }^{4}$.

Tabela 1. Dynamika wzrostu PKB oraz PKB per capita w Chinach w okresie 1980-2012.

\begin{tabular}{c|c|c} 
RoK & $\begin{array}{c}\text { PKB } \\
\text { (W MLD USD) }\end{array}$ & $\begin{array}{c}\text { PKB PER CAPITA } \\
\text { (W USD) }\end{array}$ \\
\hline 1980 & 189 & 193 \\
\hline 1990 & 356 & 314 \\
\hline 2000 & 1198 & 949 \\
\hline 2005 & 2256 & 1731 \\
\hline 2010 & 5930 & 4433 \\
\hline 2011 & 7321 & 5447 \\
\hline 2012 & 8227 & 6091
\end{tabular}

Źródło: opracowanie własne na podstawie: GDP (current US\$), The World Bank, http://data.worldbank.org/ indicator/NY.GDP.MKTP.CD/countries (23.12.2013); GDP per capita (current US\$), The World Bank, http://data. worldbank.org/indicator/NY.GDP.PCAP.CD (23.12.2013).

Szybkiemu rozwojowi gospodarczemu towarzyszył gwałtowny wzrost urbanizacji, co zasadniczo zmieniło dotychczasową konfigurację rozmieszczenia ludności w granicach państwa. W 2012 r. w strefach zurbanizowanych mieszkało już ponad 52\% mieszkańców Chin, podczas gdy w 1978 r. niespełna $18 \%$. Oznacza to, że w ciągu trzydziestu lat poziom urbanizacji w Chinach uległ niemal potrojeniu. Warto w tym zestawieniu uwzględnić dodatkowo ponad 262-milionową rzeszę migrujących pracowników ${ }^{5}$, najczęściej podejmujących pracę i egzystujących w dużych aglomeracjach miejskich. Pochodną zmian zachodzących w Chinach w ostatnich latach, będą-

\footnotetext{
${ }^{3}$ LI JIA, China Accounts for 9.5 percent of World's GDP, „People's Daily”, 25 III 2011.

${ }^{4}$ GDP per capita (current US\$), The World Bank, http://data.worldbank.org/indicator/NY. DP.PCAP.CD (23 XII 2013).

${ }^{5}$ China Should Follow Sustainable Urbanization Path, Xinhua, „China Daily”, 7 IX 2013.
} 
cych następstwem spektakularnego wzrostu gospodarczego, uprzemysłowienia oraz rosnącego poziomu urbanizacji, stało się chroniczne zapotrzebowanie na energię.

W białej księdze China's Energy Policy 2012, opublikowanej 24 października 2012 r., można było przeczytać, że w okresie 1981-2011 konsumpcja energii w Państwie Środka wzrastała w średnim tempie 5,82\% rocznie $^{6}$. Rosnący popyt na energię zaspokajają $w$ przeważającej mierze paliwa stałe, głównie węgiel. Do lat 70. to właśnie ten surowiec pokrywał aż $90 \%$ zapotrzebowania na energię. Ten współczynnik w ciągu kolejnych lat trochę się zmniejszył, ale i tak węgiel utrzymał swoją wiodącą pozycję, odpowiadając za dwie trzecie energii konsumowanej w Chinach. Biorąc pod uwagę perspektywy krótko- i długoterminowe w rozwoju sektora energetycznego, można powiedzieć, że ogólna struktura $\mathrm{z}$ dominującą pozycją węgla szybko się nie zmieni. W kontekście dyskusji na dalszym rozwojem Chin należałoby zatem zastanowić się nad odpowiedzią na pytanie nie o to, czy węgiel utrzyma swoją dominującą pozycję, ale o to, jak przekształcać ów sektor, by mógł sprostać wyzwaniom rynkowym. W tych rozważaniach należy uwzględnić przede wszystkim kwestie restrukturyzacji, podniesienia efektywności produkcyjnej oraz zintegrowania działań służących promocji czystej energii.

\section{WĘGIEL KLUCZOWYM NOŚNIKIEM ENERGII NA ŚWIECIE}

Wedle danych amerykańskiej agencji rządowej Energy Information Administration (EIA) oraz British Petroleum (BP) największymi zasobami węgla na świecie dysponują Stany Zjednoczone (28\% rezerw). Na dalszych pozycjach znajdują się Rosja (18\%), Chiny (13\%), Australia (9\%), Indie (7\%), Niemcy $(5 \%)$, pozostałe państwa $(20 \%)^{7}$

W 2002 r. produkcja węgla na świecie wynosiła $2401 \mathrm{mln}$ ton, a dziesięć lat później $3845 \mathrm{mln}$ ton $^{8}$. Wzrost wydobycia węgla na świecie notowany na przestrzeni ostatniej dekady wynikał w przeważającej mierze ze zwiększonego wydobycia w Chinach. Dla porównania w omawianym okresie produk-

\footnotetext{
${ }^{6}$ China's Energy Policy 2012, Xinhua, 24 X 2012.

${ }^{7}$ United States Leads World in Coal Reserves, Energy Information Administration, 2 IX 2011, http://www.eia.gov/todayinenergy/detail.cfm?id=2930\# (23 XII 2013).

${ }^{8}$ BP Statistical Review of World Energy, VII 2013.
} 
cja w Chinach wzrosła z $775 \mathrm{mln}$ do $1825 \mathrm{mln}$ ton, co potwierdzało jednoznacznie ich dominację w tym zakresie. W 2012 r. wydobycie w Chinach stanowiło blisko połowę wydobycia światowego ${ }^{9}$.

Tabela 2. Światowe rezerwy węgla w 2012 r. (EIA).

\begin{tabular}{c|c|c} 
Państwo & W MLN TON & UdZIAŁ PROCENTOWY \\
\hline Stany Zjednoczone & 260551 & 28 \\
\hline Rosja & 173074 & 18 \\
\hline Chiny & 126215 & 13 \\
\hline Australia & 84217 & 9 \\
\hline Indie & 66800 & 7 \\
\hline Niemcy & 44863 & 5 \\
\hline Pozostałe państwa & 192281 & 20 \\
\hline Świat (ogółem) & 948000 & 100
\end{tabular}

Źródło: World Coal Reserves, http://www.eia.gov/todayinenergy/detail.cfm?id=2930\# (23 XII 2013).

Tabela 3. Światowe rezerwy węgla w 2012 r. (BP).

\begin{tabular}{c|r|c} 
Państwo & W MLN TON & UdZIAL PROCENTOWY \\
\hline Stany Zjednoczone & 237295 & 27,6 \\
\hline Rosja & 157010 & 18,2 \\
\hline Chiny & 114500 & 13,3 \\
\hline Australia & 76400 & 8,9 \\
\hline Indie & 60600 & 7,0 \\
\hline Niemcy & 40699 & 4,7 \\
\hline Ukraina & 33873 & 3,9 \\
\hline Kazachstan & 33600 & 3,9 \\
\hline RPA & 30156 & 3,5 \\
\hline Kolumbia & 6746 & 0,8 \\
\hline Kanada & 6582 & 0,8 \\
\hline Polska & 5709 & 0,7 \\
\hline Świat (ogółem) & 860938 & 100
\end{tabular}

Źródło: BP Statistical Review of World Energy, VII 2013.

${ }^{9}$ Ibid. 
Tabela 4. Produkcja węgla na świecie w 2012 r. (BP).

\begin{tabular}{c|c|c} 
Państwo & W MLN TON & UdzIAŁ PROCENTOWY \\
\hline Chiny & 1825,0 & 47,5 \\
\hline Stany Zjednoczone & 515,9 & 13,4 \\
\hline Australia & 241,1 & 6,3 \\
\hline Indonezja & 237,4 & 6,2 \\
\hline Indie & 228,8 & 6,0 \\
\hline Rosja & 168,1 & 4,4 \\
\hline RPA & 146,6 & 3,8 \\
\hline Kazachstan & 58,8 & 1,5 \\
\hline Polska & 58,8 & 1,5 \\
\hline Kolumbia & 58,0 & 1,5
\end{tabular}

Źródło: BP Statistical Review of World Energy, VII 2013.

Tabela 5. Konsumpcja węgla na świecie w 2012 r. (BP).

\begin{tabular}{c|c|c} 
Państwo & W MLN ton & Udziat Procentowy \\
\hline Chiny & 1873,3 & 50,2 \\
\hline Stany Zjednoczone & 437,8 & 11,7 \\
\hline Indie & 298,3 & 8,0 \\
\hline Japonia & 124,4 & 3,3 \\
\hline Rosja & 93,9 & 2,5 \\
\hline RPA & 89,8 & 2,4 \\
\hline Korea Południowa & 81,8 & 2,2 \\
\hline Niemcy & 79,2 & 2,1 \\
\hline Polska & 54,0 & 1,4 \\
\hline Indonezja & 50,4 & 1,4
\end{tabular}

Źródło: BP Statistical Review of World Energy, VII 2013.

Raport Energy Information Administration (EIA) z lipca 2013 r. prognozował, że w okresie 2010-2040 konsumpcja energii na świecie wzrośnie o 56\%. Za wzrost popytu na energię odpowiadać będą przede wszystkim kraje rozwijające się. W globalnym miksie energetycznym w ciągu trzech kolejnych dekad zdecydowaną dominację utrzymają paliwa kopalne, które będą odpowiadać za $80 \%$ zapotrzebowania na energię. Pomimo że paliwa płynne, głównie ropa naftowa, pozostaną najważniejszym źródłem energii, to ich 
konsumpcja zmniejszy się z 34\% w 2010 r. do 28\% trzydzieści lat później. Zużycie węgla będzie z kolei rosło szybciej aniżeli ropy naftowej i paliw ciekłych, głównie ze względu na rosnącą konsumpcję węgla w Chinach. Popyt na węgiel w skali globalnej będzie wzrastał średnio o $1,3 \%$ rocznie $^{10}$.

Podobne wnioski nasuwają się po lekturze raportu EIA opublikowanego w grudniu 2013 r., w którym można przeczytać, że w ciągu kolejnych pięciu lat do $2018 \mathrm{r}$. popyt na węgiel na świecie będzie rósł średnio o 2,3\% rocznie. Dane te skorygowano w porównaniu z raportem przedstawionym rok wcześniej, określającym prognozy dla sektora węglowego na lata 2012-2017, gdzie mowa była o wzroście na poziomie $2,6 \%$ rocznie. Autorzy raportu uzasadniali tę zmianę nowo przyjętą przez Chiny strategią zmierzającą do zmniejszenia zależności rodzimej gospodarki od węgla. Należy zauważyć, że w przypadku samych Chin popyt na węgiel do 2018 r. będzie jednak wzrastał o 2,6\%. Oznacza to, że w ciągu tych pięciu lat wytworzą one aż $60 \%$ globalnego popytu na węgiel. Pomimo zatem podejmowanych działań służących promocji alternatywnych źródeł energii utrzyma się wysokie tempo konsumpcji paliw kopalnych ${ }^{11}$.

Jak prognozuje EIA, w latach 2010-2040 utrzyma się dominująca pozycja węgla w bilansie energetycznym Chin. Udział Chin w światowej konsumpcji węgla wzrośnie z 47\% w 2010 r. do 55\% w 2040 r. W tym samym czasie zwiększy się rola Chin w zakresie produkcji. W 2010 r. Chiny odpowiadały za $44 \%$ globalnego wydobycia. W momencie szczytowym, który przypadnie na 2030 r., ten pułap powinien wzrosnąć do 52\%. Prawie dwie trzecie wzrostu zapotrzebowania na węgiel $\mathrm{w}$ Chinach będzie przypadało na sektor elektroenergetyczny, a ponad jedna trzecia na sektor przemysłowy. ${ }^{12}$

$\mathrm{Na}$ podstawie powyższych analiz można wysunąć wniosek, że popyt i ceny węgla na międzynarodowych rynkach w zasadniczy sposób będą określane przez Chiny. Trzeba zauważyć, że wydobycie węgla w Chinach, pomimo że zdecydowanie największe na świecie, nie równoważy popytu wewnętrznego, co sprawia, że od kilku lat są one importerem węgla netto. Chiny odpowiadają za jedną trzecią rynku węgla transportowanego drogą morską w regionie Pacyfiku, co nie pozostaje bez wpływu na cały regionalny rynek węglowy. W latach 2010-2012 import węgla do Chin wzrastał średnio-

\footnotetext{
${ }^{10}$ Szerzej zob. International Energy Outlook 2013, U.S. Energy Information Administration, Washington, VII 2013.

${ }^{11}$ Szerzej zob. Medium-Term Coal Market Report 2013. Market Trends and Projections to 2018, OECD/IEA, XII 2013.

${ }^{12}$ Ibid.
} 
rocznie o $30 \%$. Korzystając z pozytywnej koniunktury wyjątkowo niskich cen na międzynarodowych rynkach, w 2011 r. Chiny zakupiły ponad 234 mln ton węgla, a w 2012 r. kolejne $289 \mathrm{mln}$ ton. Dla porównania w tym czasie wyraźnie zmniejszył się eksport węgla z Chin $^{13}$.

\section{WYZWANIA DLA SEKTORA WĘGLOWEGO W CHINACH}

Największe złoża węgla w Chinach zlokalizowane są na północy kraju. Główne ośrodki produkcyjne mieszczą się w Datong, Yanzhou, Pingdingshan, Huainan, Huaibei, Junggar ${ }^{14}$. Według danych China National Coal Association (CNCA) w 2012 r. największe wydobycie odnotowano w następujących regionach: Mongolia Wewnętrzna, Shanxi, Shaanxi, Guizhou, Henan, Anhui, Shandong, Xinjiang, Yunnan oraz Hebei. Ich łączna produkcja wyniosła w sumie 3,36 mld ton. Najlepszy wynik osiągnęła Mongolia Wewnętrzna (1061,9 mln ton), przed Shanxi (913,9 mln ton) oraz Shaanxi $(427,5 \mathrm{mln} \text { ton })^{15}$. Zestawienie obrazuje bezsprzeczną dominację dwóch obszarów Mongolii Wewnętrznej oraz Shanxi. Ten pierwszy przekroczył już pułap produkcyjny $1 \mathrm{mld}$ ton $\mathrm{w}$ ujęciu rocznym. Analogiczny schemat będzie wkrótce udziałem prowincji Shaanxi, gdzie lokalne władze zapowiedziały wydobycie $900 \mathrm{mln}$ ton w 2013 r. i podjęcie wysiłków na rzecz zwiększenia możliwości produkcyjnych do $1 \mathrm{mld}$ ton $^{16}$. Biorąc pod uwagę zarówno potencjał $\mathrm{w}$ zakresie posiadanych rezerw, jak i perspektywy nowych odkryć, uwagę zwraca również region autonomiczny Xinjiang. Szacunki wskazują, że w tym regionie występuje łącznie 2 bln ton węgla, co stanowi $40 \%$ potwierdzonych zasobów tego surowca w Chinach. W grudniu 2011 r. pojawiła się informacja o dokonaniu jednego z największych odkryć w ostatnich latach dotyczących złóż w okolicach Jeziora Sha’er w północnozachodnim Xinjiangu, szacowanych na $89,2 \mathrm{mld} \mathrm{ton}^{17}$.

${ }^{13}$ Du Juan, Survey Predicts 10\% Fall in Coal Imports, „China Daily”, 8 II 2013.

${ }^{14}$ ŁUKASZ GACEK, Bezpieczeństwo energetyczne Chin. Aktywność państwowych przedsiębiorstw na rynkach zagranicznych, Kraków: Księgarnia Akademicka, 2012, s. 43.

${ }^{15}$ William Wang, China Releases List for 2012 Top Coal Production Regions, China Coal Resource, 26 IX 2013, http://en.sxcoal.com/94641/NewsShow.html (23 XII 2013).

${ }^{16}$ JeSsIE JIA, Shanxi Sets 2013 Coal Production Target, China Coal Resource, 4 III 2013, http://en.sxcoal.com/NewsDetail.aspx?cateID=165\&id=86102\&keyword=coal\%20production (23 XII 2013).

${ }^{17}$ Asia's Largest Coal Reserve Discovered in China's Xinjiang, Xinhua, „People's Daily, 23 XII 2011. 
Charakterystyczną cechą sektora węglowego w Chinach pozostaje jego słabe zintegrowanie. W 2005 r. w kraju funkcjonowało około 25 tys. kopalni. Trzy największe przedsiębiorstwa w branży (Shenhua Coal, China National, Datong Coal) nie odpowiadały nawet za jedną szóstą produkcji ${ }^{18}$. Ostatnia dekada obrazuje jednak szereg przedsięwzięć zmierzających do fuzji spółek górniczych oraz zamykania małych i nierentownych zakładów. W tej mierze poczyniono znaczące postępy, zważywszy, że obecnie w Chinach działa około 12 tys. kopalni węgla. Nie zmieniła się jednak dotychczasowa struktura, gdyż nadal ponad $85 \%$ spośród ośrodków produkcyjnych to niewielkie kopalnie. Wydobycie $\mathrm{w}$ tych kopalniach stanowi zaledwie jedną trzecią krajowej produkcji. Dodatkowym problemem jest to, że odpowiadają one również za dwie trzecie wypadków notowanych w górnictwie ${ }^{19}$. W październiku 2013 r. rząd Chin poinformował, że w ciągu dwóch kolejnych lat zamkniętych zostanie co najmniej 2 tys. małych kopalni węgla, stwarzających zagrożenia dla zdrowia i życia ludzkiego. Zlikwidowane będą zakłady z wydobyciem rocznym nieprzekraczającym 90 tys. ton i niespełniające określonych norm bezpieczeństwa ${ }^{20}$. Należy zauważyć, że dotychczasowe rozwiązania już znacząco poprawiły warunki bezpieczeństwa w kopalniach. Dowodem na to jest fakt, że współczynnik częstości wypadków śmiertelnych na $1 \mathrm{mln}$ ton wydobytego węgla w ciągu ostatniej dekady zmniejszył się prawie dziewięciokrotnie ${ }^{21}$.

Duże rozdrobnienie w sektorze węglowym powoduje, że w Państwie Środka tylko siedem przedsiębiorstw zanotowało roczne wydobycie powyżej $100 \mathrm{mln}$ ton węgla. Odpowiadają one za jedną trzecią mocy produkcyjnych Chin, czyli około 1 mld ton. Wyniki za 2012 r. wskazywały na zdecydowaną dominację koncernu Shenhua, z wydobyciem na poziomie $456 \mathrm{mln}$ ton. W zestawieniu przygotowanym przez China National Coal Association (CNCA) w gronie pięćdziesięciu największych producentów węgla w 2012 r. było w sumie siedem spółek z produkcją przewyższającą $100 \mathrm{mln}$ ton rocznie, oraz ponad dziesięć spółek z produkcję pomiędzy 50 a $100 \mathrm{mln}$ ton. ${ }^{22}$

Plan przedstawiony przez chińską Państwowa Administrację Energetyczną (National Energy Administration - NEA) zakłada zwiększenie możli-

\footnotetext{
${ }^{18}$ GACEK, Bezpieczeństwo energetyczne Chin, s. 44.

${ }^{19}$ CHen XIn, ZHI Yun, China's Coal Mines Still Risky, „China Daily”, 25 VIII 2012.

${ }^{20}$ China to Shut Coal Mines in Safety Overhaul, Xinhua, „China Daily”, 13 X 2013.

${ }^{21}$ Ibidem.

${ }^{22}$ CNCA unveils top 100 Chinese coal companies 2013, China Coal Resource, 18 IX 2013, http://en.sxcoal.com/94343/NewsShow.html (23 XII 2013).
} 
wości produkcji węgla do 4,1 mld ton rocznie do 2015 r. Przewiduje również utworzenie $\mathrm{w}$ tym czasie dziesięciu wiodących przedsiębiorstw, których roczna produkcja będzie przekraczała $100 \mathrm{mln}$ ton, oraz kolejnych dziesięciu z produkcją roczną na poziomie $50 \mathrm{mln}$ ton. W tej sytuacji wspomniane dwadzieścia przedsiębiorstw miałoby odpowiadać za ponad $60 \%$ krajowego wydobycia. „Racjonalne kontrolowanie” wielkości produkcji ma przyczynić się do zdynamizowania rozwoju ośrodków w zachodnich Chinach. Dodane projekty w regionach autonomicznych Mongolia Wewnętrzna, Ningxia oraz Xinjiang, a także w prowincjach Shaanxi, Shanxi oraz Gansu, stanowią około $87 \%$ wszystkich nowych przedsięwzięć w sektorze węglowym. W planach związanych z restrukturyzacją sektora NEA zapowiedziała również podjęcie dalszych działań związanych z poprawą efektywności produkcyjnej. Celem zasadniczym w tym kontekście będzie zredukowanie liczby przedsiębiorstw do 4 tys. i podniesienie przypadającej na nie średniej wielkości produkcyjnej do ponad $1 \mathrm{mln}$ ton rocznie ${ }^{23}$.

Oparcie gospodarki na węglu będzie niosło z sobą wiele wyzwań. Duże rezerwy i główne ośrodki wydobywcze lokują się na północy kraju, podczas gdy największe zapotrzebowanie występuje w pasie wschodniego wybrzeża. W Chinach wydobycie węgla odbywa się w dwudziestu siedmiu prowincjach, jednakże północne obszary, głównie prowincja Shanxi oraz Mongolia Wewnętrzna, przedstawiają najkorzystniejsze warunki do eksploatacji surowca, tam też pracują największe kopalnie ${ }^{24}$. Największym ośrodkiem produkcyjnym od 2009 r. jest Mongolia Wewnętrzna, która biorąc pod uwagę plany inwestycyjne i rozwojowe, może do 2015 r. odpowiadać za jedną czwartą krajowego wydobycia ${ }^{25}$. Takie rozmieszczenie ośrodków produkcyjnych oraz potencjalnych odbiorców znacząco podnosi koszty transportu, jak również wiąże się z koniecznością rozbudowy infrastruktury przesyłowej.

W kontekście rozważań nad przyszłością sektora węglowego w Chinach należy silnie podkreślić zagadnienie związane z niedoborami wody oraz niską jakością wód. Chiny będą musiały się zmierzyć z rosnącym zapotrzebowaniem na wodę $\mathrm{w}$ związku $\mathrm{z}$ szybkim uprzemysłowieniem i urbanizacją. Niedobory wody, jej zanieczyszczenie oraz pogarszająca się ekologia wód stanowią jedno z najpoważniejszych zagrożeń dla zrównoważonego rozwoju.

\footnotetext{
${ }^{23}$ China Targets Annual Coal Production Capacity of 4.1 bln Tonnes by 2015, Xinhua, 22 III 2012.

${ }^{24}$ Country Analysis Briefs: China, U.S. Energy Information Administration (EIA), 22V 2013, http://www.eia.gov/countries/cab.cfm?fips=CH (23 XII 2013).

${ }^{25}$ GACEK, Bezpieczeństwo energetyczne Chin, s. 43.
} 
Woda odgrywa istotną rolę w rozwoju sektora energii cieplnej. Przemysł węglowy oraz elektrownie zużywają około $17 \%$ wody w Chinach. Dodatkowy problem wynika z faktu, że większość kopalni znajduje się na północy kraju, gdzie występują największe niedobory wody i gdzie zanieczyszczenie jest największe. Co najmniej $80 \%$ węgla wydobywa się w regionach, gdzie jak wskazuje Organizacja Narodów Zjednoczonych - zaopatrzenie w wodę jest albo „ograniczone”, albo występuje jej „całkowity brak”. Najpoważniejsze problemy występują w zagłębiach węglowych w Mongolii Wewnętrznej oraz prowincjach Shanxi oraz Shaanxi. Rządowy plan rozwoju przemysłu węglowego, zakładający budowę większej liczby elektrowni w pobliżu miejsc wydobycia, spowoduje, że zapotrzebowanie na wodę w tym przemyśle jeszcze wzrośnie. Tylko w Mongolii Wewnętrznej odnotuje się wzrost o 141\% do 2015 r. W porównaniu z 2010 r., co nieuchronnie będzie prowadzić do wyczerpywania się tamtejszych zasobów wodny $\mathrm{ch}^{26}$.

\section{TECHNOLOGIE WYTWARZANIA CZYSTEGO WĘGLA}

Górnictwo węglowe jeszcze długo pozostanie kluczowym sektorem gospodarki, dlatego władze centralne zamierzają zrealizować szereg poważnych przedsięwzięć zmierzających do jego unowocześnienia oraz wprowadzania nowych technologii w wytwarzaniu czystego węgla. Możliwość uzyskiwania taniej energii z węgla przy jednoczesnym ograniczaniu zanieczyszczeń środowiskowych staje się wyzwaniem $\mathrm{w}$ dokonywanej restrukturyzacji $\mathrm{w}$ górnictwie węglowym.

W marcu 2011 r. premier Wen Jiabao przedstawił plan związany z poprawą efektywności energetycznej w Chinach, który przewiduje zmniejszenie emisji dwutlenku węgla o $17 \%$ w latach $2010-2015$ oraz o $40-45 \%$ do 2020 r. w porównaniu z poziomem emisji z 2005 r. Plan zakłada również wzrost udziału paliw niekopalnych w całkowitym zużyciu energii pierwotnej ${ }^{27}$.

W przyszłości wytwarzanie nowych mocy nadal będzie odbywało się w głównej mierze w oparciu o węgiel, dlatego też istotne wyzwania pojawiają się przed największymi producentami energii takimi jak Shenhua

\footnotetext{
${ }^{26}$ Kevin Hamlin, China Coal-Fired Economy Dying of Thirst as Mines Lack Water, Bloomberg, 24 VII 2013.

${ }^{27}$ China Announces 16 pct Cut in Energy Consumption per unit of GDP by 2015, 5 III 2011, http://www.gov.cn/english/2011-03/05/content_1816947.htm (12 X 2013).
} 
Group. Spółka ta będzie musiała podjąć wysiłki na rzecz skorelowania działań służących zwiększaniu mocy przy równoczesnym zmniejszaniu negatywnego oddziaływania tych procesów na środowisko naturalne. W $2011 \mathrm{r}$. Shenhua Group dostarczała 10\% energii w Chinach oraz 4,6\% energii elektrycznej. Stąd tak ważne pozostają podejmowane przez nią działania związane z budową zaawansowanych jednostek i modernizacją już istniejących. Główne formy aktywności powinny wiązać się z poprawą efektywności energetycznej elektrowni, stworzeniem zintegrowanego systemu obejmującego niewielkie elektrownie, a także wdrożeniem mechanizmów kontroli środowiska. Jednocześnie działania te winny uwzględniać podejmowanie kompleksowych badań, wdrażanie projektów rozwojowych i demonstracyjnych dotyczących planów inwestycji w nowe elektrownie, a także uwzględniających zagadnienia związane ze zmniejszaniem emisji zanieczyszczeń ${ }^{28}$.

W Państwie Środka podjęto już pierwsze kroki na rzecz zastosowania technologii spalania w czystym tlenie, jak również podziemnego zgazowania węgla polegającego na przekształceniu paliw stałych lub płynnych o dużej zawartości węgla w paliwa gazowe za pomocą powietrza lub czystego tlenu przy dodaniu pary wodnej (carbon dioxide capture and storage - CCS). Technologia CCS obejmuje trzy etapy: wychwytywanie, transport oraz składowanie. W pierwszym etapie następuje oddzielenie dwutlenku węgla od innych gazów wytwarzanych w trakcie spalania paliw kopalnych i innych procesach przemysłowych. W drugim sprężony $\mathrm{CO}_{2}$ jest transportowany do miejsca składowania. Obecnie najczęściej odbywa się to z wykorzystaniem rurociągów, statków bądź cystern. W ostatnim etapie $\mathrm{CO}_{2}$ jest składowany na dużych głębokościach w podziemnych formacjach skalnych ${ }^{29}$.

W zakresie wykorzystania tej technologii Chiny osiągnęły już pierwsze wymierne efekty. 1 czerwca 2009 r. koncern China Shenhua Coal Liquefaction and Chemical Co., Ltd rozpoczął realizację programu wychwytywania i podziemnego zgazowania węgla w Ordos na terytorium Mongolii Wewnętrznej. Plan przewidywał wychwycenie i podziemne zgazowanie 100 tys. ton dwutlenku węgla rocznie ${ }^{30}$. W październiku 2013 r. zakończył się

${ }^{28}$ Chen YinBiaO, Clean and High-Efficiency Coal-Fired Power Generation in the Shenhua Group, „Corner Stone. The Official Journal of the World Coal Industry”, Spring 2013, vol. 1, s. $60-64$.

${ }^{29}$ The Global Status of CCS: 2012, Global CCS Institute, Canberra 2012, s. 9, http://cdn. globalccsinstitute.com/sites/default/files/publications/47936/global-status-ccs-2012.pdf (23 XII 2013).

${ }^{30}$ Shenhua Launches China's First Carbon Capture and Storage Program, „People's Daily”, 3 VI 2010. 
pierwszy z trzech etapów projektu zgazowana węgla w Mongolii Wewnętrznej, dzięki któremu od końca roku do Pekinu mogą docierać dostawy gazu ziemnego. Inwestycja ma przyczynić się do redukcji zanieczyszczeń w stolicy. Bazując na sporym potencjale surowcowym, Mongolia Wewnętrzna ma szansę stać się głównym dostawcą czystej energii dla stolicy oraz północnych regionów kraju. Poza Mongolią Wewnętrzną projekty zgazowania węgla są wdrażane w Xinjiangu, a także w prowincjach Shanxi oraz Liaoning $^{31}$. Realizacja kolejnych projektów wydaje się jedynie kwestią czasu.

Global CCS Institute do sierpnia 2013 r. zidentyfikował na świecie sześćdziesiąt pięć dużych zintegrowanych projektów związanych z CCS. Spośród wszystkich instalacji dwanaście było funkcjonalnych, najwięcej, bo aż siedem, w Stanach Zjednoczonych. Czterdzieści pięć projektów pozostaje w dalszym ciągu na etapie planowania. Uwzględniając wszystkie fazy obejmujące planowanie, realizację $\mathrm{i}$ działanie, na Chiny przypadało $\mathrm{w}$ sumie dwanaście projektów, mniej tylko od USA (20) i Europy (15) ${ }^{32}$. Najbardziej zaawansowane projekty realizują obecnie państwowe przedsiębiorstwa, tj. Sinopec oraz Petrochina ${ }^{33}$.

Raport Global Climate Leadership Review 2013, przygotowany przez australijski Climate Institute wskazywał na region Azji, a w szczególności Chiny jako centrum działań na rzecz rozwoju niskoemisyjnej gospodarki. W rankingu Chiny lokowały się na trzeciej pozycji, ustępując miejsca jedynie Francji i Japonii. Podkreślano, że odnotowały one znaczący awans, będący wynikiem rosnących nakładów na rozwój czystej energii, wzrostu w eksporcie zaawansowanej technologii, jak również wysokich inwestycji w czystą energię dokonanych z udziałem spółek publicznych ${ }^{34}$.

W kwietniu 2013 r. Państwowa Komisja ds. Rozwoju i Reform (National Development and Reform Commission) przedstawiła strategię rozwoju technologii wychwytywania, wykorzystania i składowania $\mathrm{CO}_{2}$ w Chinach. Podkreślono, że technologia ta posiada znaczący potencjał, służący redukcji emisji gazów cieplarnianych do atmosfery. Ma to znaczenie w kontekście

${ }^{31}$ China's First Coal-to-Gas Project Ready, Xinhua, 31 X 2013.

${ }^{32}$ The Global Status of CCS: 2013, Global CCS Institute, Melbourne 2013, s. 27, http://cdn. globalccsinstitute.com/sites/default/files/publications/116211/global-status-ccs-2013.pdf (23 XII 2013).

${ }^{33}$ The Global Status of CCS: 2013, Global CCS Institute, Melbourne 2013, s. 41, http://cdn. globalccsinstitute.com/sites/default/files/publications/116211/global-status-ccs-2013.pdf (23 XII 2013).

${ }^{34}$ Szerzej zob. The Climate Institute, Global Climate Leadership Review 2013, Sydney 2013. 
realizacji średnio- i długoterminowych planów Chin dotyczących walki ze zmianami klimatycznymi oraz promocją rozwoju technologii niskowęglowych. Plan krótkoterminowy zakłada rozwój projektów pilotażowych i demonstracyjnych związanych z rozwojem technologii, określenie zasad wsparcia finansowego dla tych przedsięwzięć, rozszerzenie strategicznych badań i planowania służących rozwojowi tego sektora, współpracę zagraniczną, a także podniesienie świadomości społecznej w zakresie zastosowania tej technologii. To, co zwraca jednak szczególną uwagę, to zapowiedź wprowadzenia właściwych standardów i regulacji dotyczących stosowania procesu sekwestracji, w powiązaniu z jego wpływem na zdrowie ludzkie, bezpieczeństwo i środowisko ${ }^{35}$.

\section{WSPÓŁPRACA ZAGRANICZNA W PROMOWANIU CZYSTEJ ENERGII}

Istotne znaczenie w kontekście rozwoju technologii CCS w Chinach odgrywa współpraca ze Stanami Zjednoczonymi oraz Unią Europejską, które dysponują sporym doświadczeniem i odpowiednią wiedzą w tym obszarze.

17 listopada 2009 r., podczas wizyty przewodniczącego Hu Jintao w Waszyngtonie, Chiny i USA podpisały szereg porozumień dotyczących współpracy w zakresie rozwoju czystej energii. Padła wówczas zapowiedź utworzenia centrum badawczego ds. rozwoju czystej energii. Przy udziale naukowców amerykańskich i chińskich miało ono koncentrować swoje działania w pierwszej kolejności na kwestiach związanych z budowaniem efektywności energetycznej, rozwojem technologii czystego węgla (w tym sekwestracją dwutlenku węgla), jak również promowaniem energooszczędnych pojazdów ${ }^{36}$.

\footnotetext{
${ }^{35}$ Notice of National Development and Reform Commission (NDRC) on Promoting Carbon Capture, Utilisation and Storage Pilot and Demonstration, NDRC Climate [2013] Document No. 849, 27 IV 2013, http://cdn.globalccsinstitute.com/sites/default/files/publications/102106/noticenational-development-reform-commission-ndrc.pdf (23 XII 2013).

${ }^{36}$ U.S.-China Clean Energy Announcements, The White House. Office of the Press Secretary, 17 XI 2009, http://www.whitehouse.gov/the-press-office/us-china-clean-energy-announcements (23 XII 2013); U.S.-China Cooperation on 21st Century Coal, The White House. Office of the Press Secretary, 17 XI 2009, http://www.whitehouse.gov/files/documents/2009/november/USChina-Fact-Sheet-on-Coal.pdf (23 XII 2013); U.S.-China Energy Efficiency Action Plan, The White House. Office of the Press Secretary, 17 XI 2009, http://www.whitehouse.gov/ files/ documents/2009/november/US-China-Fact-Sheet-on-Efficiency-Action-Plan.pdf (23 XII 2013);
} 
Podpisane porozumienia otworzyły przed Chinami nową perspektywę w kontekście pozyskiwania zaawansowanej technologii, niezbędnej dla rozwoju odnawialnych źródeł energii. Stany Zjednoczone dysponują technologią i know-how, podczas gdy Chiny mają ogromny potencjał rynkowy i spore umiejętności produkcyjne, co może przynieść wymierne rezultaty w kontekście rozwoju dalszej współpracy.

Analogiczny schemat działania dostrzegalny jest w stosunkach Chin z Unią Europejską. Współpraca w dziedzinie energetycznej sięga 1994 r. Od 2005 r. prowadzony jest regularny dialog energetyczny UE-Chiny. Głównymi obszarami zainteresowania dwóch stron w płaszczyźnie energetycznej pozostają odnawialne źródła energii, rozwój inteligentnych sieci energetycznych, efektywność energetyczna w sektorze budowlanym, rozwój czystego węgla, energetyki jądrowej oraz uregulowań prawnych. Uwagę władz w Pekinie zwracają przede wszystkim europejskie rozwiązania technologiczne, co pozostaje szczególnie istotne w kontekście zwiększania innowacyjności, poprawy efektywności, wykorzystywania zasobów, jak również radzenia sobie ze zmianami klimatu.

W rozmowach dwustronnych często poruszaną kwestią pozostają zagadnienia dotyczące zmian klimatycznych. W 2005 r. powołano Partnerstwo UE-Chiny w dziedzinie zmian klimatu, w ramach którego wdrażane są programy służące ograniczaniu emisji zanieczyszczeń. Jedną z inicjatyw tego forum jest projekt SNAPP (Supporting National Assessments of Post-2012 Proposals for Climate Protection and Sustainable Development), udzielający pomocy krajom rozwijającym się, pod kątem oceny różnych propozycji międzynarodowych ustaleń w zakresie zmian klimatycznych po 2012 r., na tle narodowych planów zrównoważonego rozwoju ${ }^{37}$.

W ramach Partnerstwa UE-Chiny w dziedzinie zmian klimatu wiele miejsca poświęca się dyskusji na temat upowszechniania systemu CCS oraz innych czystych technologii. Na podkreślenie zasługuje inicjatywa finansowania projektu budowy elektrowni węglowej o niemal zerowej emisji (Near Zero Emissions Coal). W momencie ustanawiania Partnerstwa UE-Chiny $\mathrm{w}$ dziedzinie zmian klimatu pojawiło się polityczne zobowiązanie „w spra-

U.S.-China Electric Vehicles Initiative, The White House. Office of the Press Secretary, 17 XI 2009, http://www.whitehouse.gov/files/documents/2009/november/US-China-Fact-Sheet-on-ElectricVehicles.pdf (23 XII 2013).

${ }^{37}$ Działania UE przeciw zmianom klimatu. Wspótpraca z krajami rozwijającymi się na rzecz przeciwdziałania zmianom klimatu, Komisja Europejska, Urząd Oficjalnych Publikacji Wspólnot Europejskich, Luksemburg 2008, s. 15. 
wie opracowania i demonstracji w Chinach i UE do 2020 r. zaawansowanej technologii o niemal zerowej emisji dwutlenku węgla (NZEC), opartej na wychwytywaniu i składowaniu dwutlenku węgla (CCS)" ${ }^{38}$. Do 2020 r. w Chinach ma powstać pokazowa elektrownia wytwarzająca energię przy niemal zerowej emisji gazów ${ }^{39}$.

Unia Europejska rozwija szereg projektów z wykorzystaniem czystych technologii na rzecz redukcji emisji gazów cieplarnianych w krajach rozwijających się. Stara się to czynić zgodnie z zapisami Ramowej Konwencji Narodów Zjednoczonych w sprawie zmian klimatu, protokołu z Kioto oraz określonego w nim mechanizmu czystego rozwoju (Clean Development Mechanism - CDM), a także za pomocą regionalnej i dwustronnej współpracy z krajami partnerskimi. W ramach programu SYNERGY organizacje w Unii Europejskiej oraz Chinach, Indiach, Ameryce Łacińskiej, Afryce, na Karaibach i w Zatoce Perskiej realizują kilkanaście projektów rozwoju kompetencji do działania, wspomagając propagowanie wiedzy na temat czystego rozwoju. Mechanizm CDM służy realizacji celów w ramach Partnerstwa UE-Chiny na rzecz przeciwdziałania zmianom klimatu. Wśród przykładów wymienić należy uruchomiony w połowie $2007 \mathrm{r}$. i realizowany przez trzy lata, największy projekt finansowany przez Unię Europejską w ramach Partnerstwa, stwarzający bezpośrednie wsparcie dla rozwoju mechanizmu CDM w Państwie Środka. Program realizowany był w postaci badań naukowych, rozwoju kompetencji do działania, podnoszenia świadomości, współpracy technicznej i szkolenn ${ }^{40}$.

Unia Europejska prowadziła z Chinami również wspólne badania nad klimatem. W ramach projektu TOCSIN UE wespół z instytutami badawczymi z Chin i Indii badała warianty redukcji gazów cieplarnianych w tych krajach. Koncentrowano się przede wszystkim na najważniejszych sektorach przemysłowych i technologicznych, obejmujących produkcję energii, rolnictwo i transport. W latach 2006-2009, również z udziałem Chin i Indii, realizowany był projekt strategii adaptacji i ograniczania, którego głównym celem było pogłębienie znajomości efektów synergii, kompromisów i konfliktów między polityką adaptacji a polityką łagodzenia skutków ${ }^{41}$. W latach 2006-

${ }^{38}$ Demonstrating Carbon Capture and Geological Storage (CCS) in Emerging Developing Countries: Financing the EU-China Near Zero Emissions Coal Plant Project, Commission of the European Communities, Brussels, June 25, 2009.

${ }^{39}$ Ibid.

${ }^{40}$ Działania UE przeciw zmianom klimatu, s. 20.

${ }^{41}$ Ibid., s. 24-25. 
-2008 przy współudziale UE wdrożono kolejny program badawczy - model synergii i interakcji gazów cieplarnianych i zanieczyszczenia powietrza (Greenhouse Gas and Air Pollution Interactions and Synergies), określający koszty emisji i ich ograniczeń w zakresie pospolitych zanieczyszczeń powietrza $^{42}$. Warto wspomnieć jeszcze o utworzonym w 2010 r. w Uniwersytecie Tsinghua w Pekinie Europejsko-Chińskim Centrum Czystej Energii, którego zadaniem jest promocja wykorzystania w większym stopniu czystej energii.

Obok współpracy ze Stanami Zjednoczonymi i Unią Europejską Chiny przedsięwzięły szereg projektów związanych z rozwojem czystej energii z Australią. W ramach Asia Pacific Partnership on Clean Development and Climate Chiny współpracują z Australią w realizacji projektu podziemnego składowania dwutlenku węgla. Pierwsza faza projektu rozwijana przy wsparciu finansowym rządu Australii była realizowana w latach 2009-2012. Druga faza, również finansowana przez Australię, zaplanowana została na lata 2012-2014. Działania koncentrować się będą na organizacji warsztatów technicznych i szkół letnich, realizacji przedsięwzięć badawczych pozywających określić warunki geologiczne składowania $\mathrm{CO}_{2}$, a także wymian naukowych i studenckich pomiędzy obydwoma państwami. ${ }^{43}$

\section{WNIOSKI}

Węgiel w przyszłości nadal będzie odgrywał kluczową rolę w budowaniu bezpieczeństwa energetycznego Chin. Argumentami przemawiającymi za węglem są ogromne zasoby własne, łatwość dostępu, jak i stosunkowo niska cena $\mathrm{w}$ porównaniu z innymi nośnikami energii. Sektor wymaga jednak podjęcia szeregu reform służących podniesieniu jego konkurencyjności. Zasadnicze wyzwania będą wiązały się z redukcją kosztów produkcji, jak też poprawą efektywności w zakresie jego wykorzystywania. Chiny powinny w szerokim zakresie rozwijać technologie węglowe. Pozytywnym objawem są w tej materii powstające w szybkim tempie instalacje pilotażowe i demonstracyjne.

\footnotetext{
${ }^{42}$ Ibid.

${ }^{43}$ Szerzej zob. International Carbon Capture and Storage Project, http://www.ga.gov.au/ ghg/projects/international-ghg.html, China Australia Geological Storage of CO2 (CAGS), http://www.cagsinfo.net/ (23 XII 2013).
} 
Promocja odnawialnych źródeł energii nie będzie stanowić realnej alternatywy dla węgla w przewidywalnej przyszłości. Należy tu zaznaczyć, że Chiny są największym emitentem $\mathrm{CO}_{2}$ na świecie, ale jednocześnie od kilku lat pozostają również największym globalnym inwestorem w zieloną energię. Proces dekarbonizacji w Chinach, mający służyć redukcji emisji zanieczyszczeń środowiskowych, odbywa się wedle określonych reguł. Chiny indywidualnie wyznaczają cele $\mathrm{i}$ metody $\mathrm{w}$ zakresie ograniczania emisji $\mathrm{CO}_{2}$. Kluczową rolę będzie tu odgrywał rozwój innowacyjnych rozwiązań w sektorze nowej energii.

Legitymizacja rządzącej w Chinach partii komunistycznej zależy w głównej mierze od stanu rodzimej gospodarki. Utrzymanie stabilności wewnątrz państwa, jak również jego konkurencyjność na arenie międzynarodowej warunkowana będzie zdolnościami władz centralnych w zakresie pomyślnej realizacji polityki rozwojowej. Chiny, chcąc utrzymać dotychczasowe wysokie tempo wzrostu gospodarczego, muszą zapewnić sobie szeroki dostęp do taniej energii.

\section{BIBLIOGRAFIA}

Asia's Largest Coal Reserve Discovered in China's Xinjiang, Xinhua, „People's Daily, 23 XII 2011.

BP Statistical Review of World Energy, VII 2013.

Chen, Xin \& Zhi, Yun. China's Coal Mines Still Risky, „China Daily”, 25 VIII 2012.

Chen, Yinbiao. Clean and High-Efficiency Coal-Fired Power Generation in the Shenhua Group, „Corner Stone. The Official Journal of the World Coal Industry”, Spring 2013, vol. 1, s. 60-64.

China 2012 Growth Eases to 7.8 pct, Xinhua, 18 I 2013.

China Announces 16 pct Cut in Energy Consumption per unit of GDP by 2015, 5 III 2011, http://www.gov.cn/english/2011-03/05/content_1816947.htm (12 X 2013).

China GDP, Trading Economics, http://www.tradingeconomics.com/china/gdp (23 XI 2013).

China Should Follow Sustainable Urbanization Path, Xinhua, „China Daily”, 7 IX 2013.

China Targets Annual Coal Production Capacity of 4.1 bln Tonnes by 2015, Xinhua, 22 III 2012.

China to Shut Coal Mines in Safety Overhaul, Xinhua, „China Daily”, 13 X 2013.

China's Energy Policy 2012, Xinhua, 24 X 2012.

China's First Coal-to-Gas Project Ready, Xinhua, 31 X 2013.

CNCA unveils top 100 Chinese coal companies 2013, China Coal Resource, 18 IX 2013, http://en.sxcoal.com/94343/NewsShow.html (23 XII 2013).

Country Analysis Briefs: China, U.S. Energy Information Administration (EIA), 22V 2013, http://www.eia.gov/countries/cab.cfm?fips=CH (23 XII 2013).

Demonstrating Carbon Capture and Geological Storage (CCS) in Emerging Developing Countries: Financing the EU-China Near Zero Emissions Coal Plant Project, Commission of the European Communities, Brussels, June 25, 2009.

Du, Juan, Survey Predicts 10\% Fall in Coal Imports, „China Daily”, 8 II 2013. 
Działania UE przeciw zmianom klimatu. Wspótpraca z krajami rozwijającymi się na rzecz przeciwdziałania zmianom klimatu, Komisja Europejska, Urząd Oficjalnych Publikacji Wspólnot Europejskich. Luksemburg, 2008.

GACEK, ŁUKASZ. Bezpieczeństwo energetyczne Chin. Aktywność państwowych przedsiębiorstw na rynkach zagranicznych. Kraków: Księgarnia Akademicka, 2012.

GDP per capita (current US\$), The World Bank, http://data.worldbank.org/indicator/NY.DP. PCAP.CD (23 XII 2013).

Hamlin, Kevin. China Coal-Fired Economy Dying of Thirst as Mines Lack Water. Bloomberg, 24 VII 2013.

International Carbon Capture and Storage Project, http://www.ga.gov.au/ghg/projects/internationalghg.html, China Australia Geological Storage of $\mathrm{CO}_{2}$ (CAGS), http://www. cagsinfo.net/ (23 XII 2013).

International Energy Outlook 2013, U.S. Energy Information Administration, Washington, VII 2013.

JiA, JeSSIE. Shanxi Sets 2013 Coal Production Target, China Coal Resource, 4 III 2013, http://en.sxcoal.com/NewsDetail.aspx?cateID $=165 \& \mathrm{id}=86102 \&$ keyword $=$ coal $\% 20$ production (23 XII 2013).

LI, JIA. China Accounts for 9.5 percent of World's GDP, „People’s Daily”, 25 III 2011.

Medium-Term Coal Market Report 2013. Market Trends and Projections to 2018, OECD/IEA, XII 2013.

Notice of National Development and Reform Commission (NDRC) on Promoting Carbon Capture, Utilisation and Storage Pilot and Demonstration, NDRC Climate [2013] Document No. 849, 27 IV 2013, http://cdn.globalccsinstitute.com/sites/default/files/publications/102106/ notice-national-development-reform-commission-ndrc.pdf (23 XII 2013).

Shenhua Launches China's First Carbon Capture and Storage Program, „People’s Daily”, 3 VI 2010.

The Climate Institute, Global Climate Leadership Review 2013, Sydney 2013.

The Global Status of CCS: 2012, Global CCS Institute, Canberra 2012, http://cdn.globalccs institute.com/sites/default/files/publications/47936/global-status-ccs-2012.pdf (23 XII 2013).

The Global Status of CCS: 2013, Global CCS Institute, Melbourne 2013, http://cdn.globalccs institute.com/sites/default/files/publications/116211/global-status-ccs-2013.pdf (23 XII 2013).

U.S.-China Clean Energy Announcements, The White House. Office of the Press Secretary, 17 XI 2009, http://www.whitehouse.gov/the-press-office/us-china-clean-energy-announcements (23 XII 2013),

U.S.-China Cooperation on 21st Century Coal, The White House. Office of the Press Secretary, 17 XI 2009, http://www.whitehouse.gov/files/documents/2009/november/US-China-Fact-Sheeton-Coal.pdf (23 XII 2013),

U.S.-China Electric Vehicles Initiative, The White House. Office of the Press Secretary, 17 XI 2009, http://www.whitehouse.gov/files/documents/2009/november/US-China-Fact-Sheet-on-ElectricVehicles.pdf (23 XII 2013).

U.S.-China Energy Efficiency Action Plan, The White House. Office of the Press Secretary, 17 XI 2009, http://www.whitehouse.gov/files/documents/2009/november/US-China-Fact-Sheet-onEfficiency-Action-Plan.pdf (23 XII 2013),

United States Leads World in Coal Reserves, Energy Information Administration, 2 IX 2011, http://www.eia.gov/todayinenergy/detail.cfm?id=2930\# (23 XII 2013).

Wang, William. China Releases List for 2012 Top Coal Production Regions, China Coal Resource, 26 IX 2013, http://en.sxcoal.com/94641/NewsShow.html (23 XII 2013). 


\section{SEKTOR WĘGLOWY W SYSTEMIE ENERGETYCZNYM CHIN \\ - PERSPEKTYWY ROZWOJOWE}

Streszczenie

Artykuł przedstawia schemat wykorzystywania węgla i jego rolę w polityce energetycznej Chin. Określa również następstwa podejmowanych działań dla rozwoju gospodarczego i społecznego państwa. Chińskie zapotrzebowanie na energię nie ma wymiaru jedynie ekonomicznego, ale decyduje również o ogólnej strategii rozwojowej. Wpływa na aspiracje Chin w kontekście zdobywania należnej pozycji w przestrzeni globalnej oraz na to, czy Chiny będą miały szansę stać się odpowiedzialnym światowym liderem w zakresie ochrony środowiska.

Słowa kluczowe: polityka energetyczna Chin, bezpieczeństwo energetyczne Chin, węgiel, technologie wytwarzania czystego węgla, środowisko.

Key words: China's energy policy, China's energy security, coal, clean coal generation technologies, environment. 